Radiocarbon, Vol 57, Nr 5,201, Goprected Proofs

DOI: $10.2458 / a z u \_r c .57 .18179$

(C) 2015 by the Arizona Board of Regents on behalf of the University of Arizona

\title{
BAYESIAN CHRONOLOGICAL MODELING OF SUNWATCH, A FORT ANCIENT VILLAGE IN DAYTON, OHIO
}

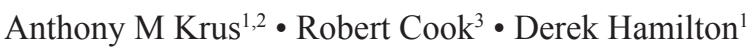

ABSTRACT. Radiocarbon results from houses, pits, and burials at the SunWatch site, Dayton, Ohio, are presented within an interpretative Bayesian statistical framework. The primary model incorporates dates from archaeological features in an unordered phase and uses charcoal outlier modeling (Bronk Ramsey 2009b) to account for issues of wood charcoal ${ }^{14} \mathrm{C}$ dates predating their context. The results of the primary model estimate occupation lasted for $1-245 \mathrm{yr}$ (95\% probability), starting in cal AD 1175-1385 (95\% probability) and ending in cal AD 1330-1470 (95\% probability). An alternative model was created by placing the ${ }^{14} \mathrm{C}$ dates into two unordered phases corresponding with horizontal stratigraphic relationships or distinct groups of artifacts thought to be temporally diagnostic. The results of the alternative model further suggest that there is some temporal separation between Group 1 and Group 2, which seems more likely in the event of a multicomponent occupation. Overall, the modeling results provide chronology estimates for SunWatch that are more accurate and precise than that provided in earlier studies. While it is difficult to determine with certainty if SunWatch had a single-component or multicomponent occupation, it is clear that SunWatch's occupation lasted until the second half of the AD 1300s.
\end{abstract}

\section{INTRODUCTION}

Scholars have long grappled with chronological issues as they pertain to individual Fort Ancient site histories (e.g. Prufer and Shane 1970:232-5; Hanson 1975:101; Brose 1982:55-8; Cowan et al. 1990; Henderson et al. 1992; Drooker 1997:137-41; Henderson 1998; Cook 2007; Nolan 2011, 2012). These studies have generally suffered by being based on inadequate numbers of radiocarbon dates per individual site. However, when large numbers of dates are present for individual sites, multiple occupations have been hypothesized (e.g. Drooker 1997; Cook 2007). Furthermore, no previous investigation has employed Bayesian methods for refining respective site chronologies.

SunWatch, located in Dayton, Ohio, is a circular Fort Ancient (AD 1000-1670) village with a large center pole and plaza surrounded by burials, pit features, houses, and a stockade (Figure 1; Heilman et al. 1988; Cook 2008). The chronology of SunWatch has been a topic of enquiry and debate since excavations began nearly 5 decades ago. Prior to ${ }^{14} \mathrm{C}$ dating, occupation was believed to have lasted roughly $20 \mathrm{yr}$ because of the low rate of feature overlap (Figure 1) and overall artifact homogeneity. Turnbow (1989) challenged this by noting that calibrated ${ }^{14} \mathrm{C}$ results from SunWatch and other Fort Ancient settlements spanned several centuries. Based on this observation, Turnbow (1989) concluded that SunWatch had a multicomponent occupation lasting from the AD 1100s to the 1300s. More recently, Cook (2007) observed that each occupation scenario has merits based on an analysis of the distributions of the ${ }^{14} \mathrm{C}$ dates, architectural rebuilding, feature form, feature volume, and diagnostic artifact attributes. Cook (2007) concluded that it was possible that occupation lasted a total of 10 to $30 \mathrm{yr}$ in the late AD 1200s and early AD 1300s, although also agreed that a multicomponent occupation lasting from the late $\mathrm{AD} 1100$ s to the mid- to late $\mathrm{AD} 1300$ s was also plausible.

Advances in the statistical modeling of ${ }^{14} \mathrm{C}$ dates and archaeological data within a Bayesian framework have allowed researchers to better understand site chronologies and even produce date estimates at generational levels (Bayliss et al. 2007, 2011; Bayliss 2009). In the case of SunWatch, what is of interest is the timing of occupation because it directly addresses the contrasting occupation scenarios summarized by Cook (2007). The chronology of this activity can be estimated not only by using the absolute dating provided by the ${ }^{14} \mathrm{C}$ measurements, but also by utilizing the relative dating information provided by stratigraphy and feature groupings. Bayesian modeling of ${ }^{14} \mathrm{C}$ data and the archaeological evidence have allowed for estimates of the site chronology that address the conclusions of previous research.

1. SUERC, Scottish Enterprise Technology Park, Rankine Avenue East Kilbride G75 0QF, Scotland, United Kingdom.

2. Corresponding author. Email: tony.krus@glasgow.ac.uk.

3. Ohio State University, Department of Anthropology, Newark Campus, 1179 University Drive, Newark, OH 43055-1797. 


\section{Corrected Proofs}

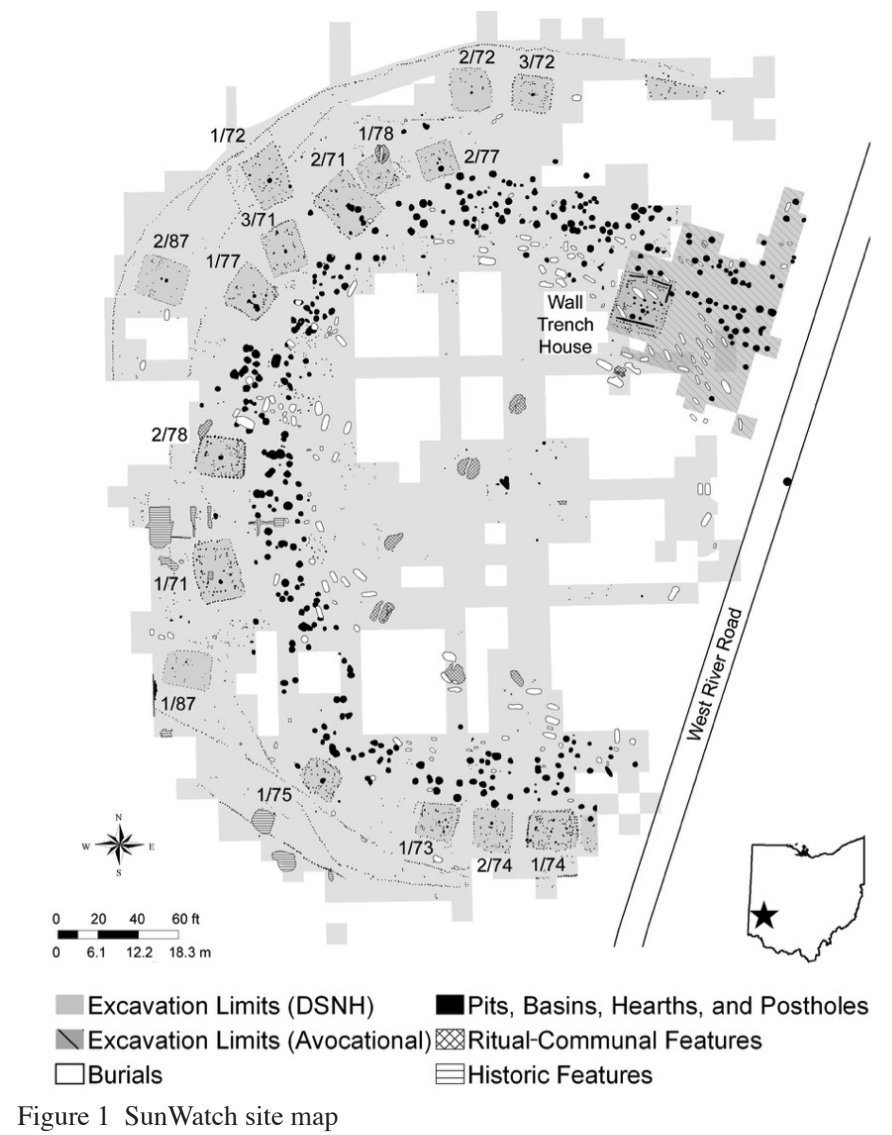

The initial $14{ }^{14} \mathrm{C}$ age measurements for SunWatch have standard deviations greater than $\pm 60{ }^{14} \mathrm{C}$ yr (Table 1). Archaeologists did not consider SunWatch to have a longer chronology until the creation of a data set of ${ }^{14} \mathrm{C}$ measurements in the 1970 s and the 1980s. Presently, these older ${ }^{14} \mathrm{C}$ results greatly decrease the temporal clarity of occupation because the calibrated probability distributions are greater than $150 \mathrm{yr}$ (Figure 2, Table 1). However, the posterior probabilities of ${ }^{14} \mathrm{C}$ dates with large standard deviations potentially can become informative in Bayesian chronological models of robust ${ }^{14} \mathrm{C}$ data when there is also a high number of small standard error dates informing the model (Steier and Rom 2000; Bayliss et al. 2011; Jay et al. 2012).

The $95 \%$ confidence ranges for calibrated probability distributions from ${ }^{14} \mathrm{C}$ measurements with standard deviations of $\pm 35 \mathrm{yr}$ that intersect a calibration curve wiggle covering cal AD 1290-1410 can span well over a hundred calendar years (Figure 2, Table 1), thereby greatly decreasing the resolution of Fort Ancient chronologies. Wiggles are present in the calibration curve due to the fluctuations in levels of atmospheric ${ }^{14} \mathrm{C}$ production from factors such as variation in the Earth's magnetic fields, climatic change, and sunspot activity (Aitken 1990). Figure 2 demonstrates how the calibration curve treats a ${ }^{14} \mathrm{C}$ date near the middle of the cal AD 1290-1410 wiggle, as well as both before and after. The smearing effect of this wiggle presents a major problem for understanding the chronology of SunWatch because it makes it difficult to evaluate the scenario of a 10-30 yr occupation (Baillie 1991), although Steier and Rom (2000) and Bayliss et al. (2007) demonstrate with simulations that Bayesian modeling of robust ${ }^{14} \mathrm{C}$ data sets that reliably date the events of interest can potentially overcome calibration curve wiggles. 


\section{Corrected Proofs}

Bayesian Chronological Modeling of SunWatch

To enhance the Bayesian modeling, five samples were selected from previously dated features and submitted to the Scottish Universities Environmental Research Centre (SUERC) for new AMS ${ }^{14} \mathrm{C}$ measurements to create a more robust ${ }^{14} \mathrm{C}$ data set. The new SUERC ${ }^{14} \mathrm{C}$ measurements have standard deviations less than $\pm 33{ }^{14} \mathrm{C}$ yr, providing an overall tighter chronological control.

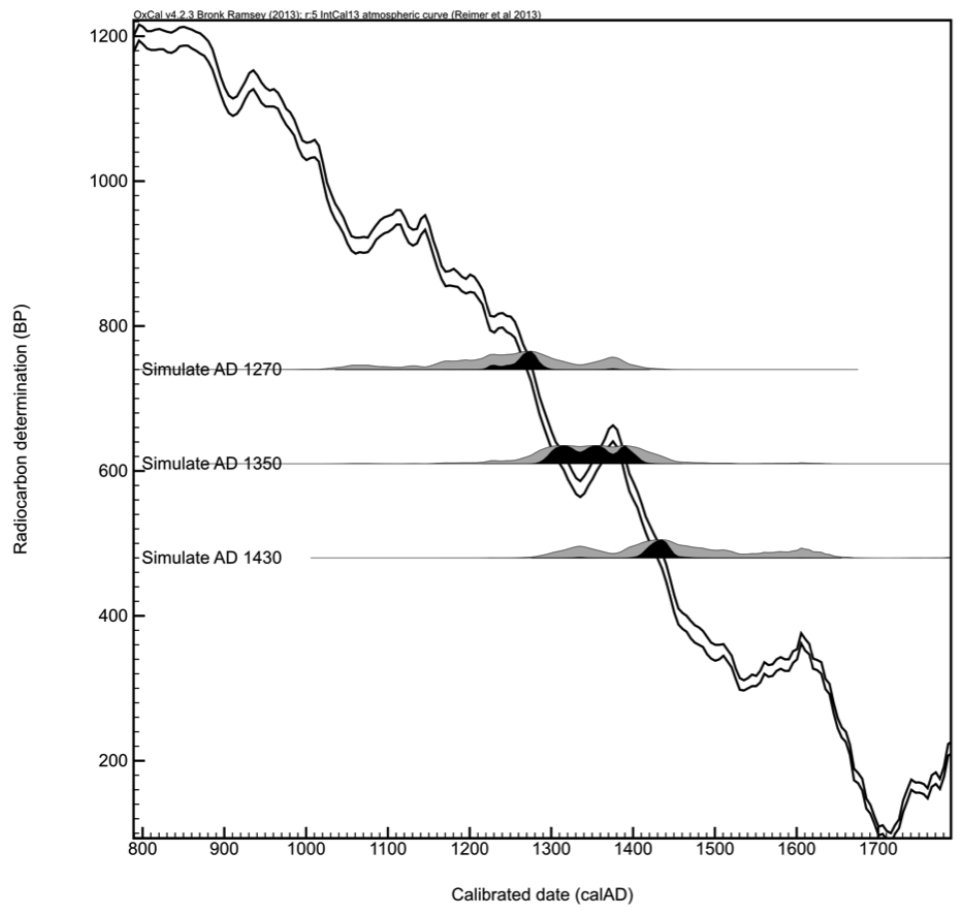

Figure 2 IntCal13 (Reimer et al. 2013) calibration curve with probability distributions of simulated ${ }^{14} \mathrm{C}$ dates for $\mathrm{AD} 1270,1350$, and 1475 . The solid black calibrated probability distributions are from simulated ${ }^{14} \mathrm{C}$ measurements with standard deviation of \pm 35 yr. The solid gray calibrated probability distributions are from simulated ${ }^{14} \mathrm{C}$ measurements with standard deviation of $\pm 100 \mathrm{yr}$.

Table 1 SunWatch radiocarbon ages.

\begin{tabular}{|c|c|c|c|c|c|c|}
\hline Lab code & Context & Material & $\begin{array}{l}\delta^{13} \mathrm{C} \\
(\%)\end{array}$ & $\begin{array}{l}\text { Conv. }{ }^{14} \mathrm{C} \\
\text { age (BP) }\end{array}$ & $\begin{array}{l}\text { Calib. range } \\
(95 \% \text { conf.) }\end{array}$ & Reference \\
\hline Beta-220062 & Burial 5/78 & human bone & -11.8 & $700 \pm 40$ & $\begin{array}{l}\text { cal AD } \\
1240-1400\end{array}$ & This paper \\
\hline Beta-220061 & Burial 8/74 & human bone & -12.2 & $660 \pm 40$ & $\begin{array}{l}\text { cal AD } \\
1270-1400\end{array}$ & This paper \\
\hline A-0175 & $\begin{array}{l}\text { Feature } 1 / 77 \text { bell- } \\
\text { shaped pit }\end{array}$ & bean & -26.5 & $652 \pm 42$ & $\begin{array}{l}\text { cal AD } \\
1270-1400\end{array}$ & Hart et al. 2002:381 \\
\hline Beta-184242 & $\begin{array}{l}\text { House } 2 / 78 \text { post- } \\
\text { hole }\end{array}$ & $\begin{array}{l}\text { unidentified } \\
\text { wood charcoal }\end{array}$ & n.a. ${ }^{1}$ & $520 \pm 60$ & $\begin{array}{l}\text { cal AD } \\
1290-1470\end{array}$ & Cook 2007:Table 1 \\
\hline Beta-184243 & $\begin{array}{l}\text { House } 2 / 71 \text { post- } \\
\text { hole }\end{array}$ & $\begin{array}{l}\text { unidentified } \\
\text { wood charcoal }\end{array}$ & n.a. ${ }^{1}$ & $850 \pm 40$ & $\begin{array}{l}\text { cal AD } \\
1040-1270\end{array}$ & Cook 2007:Table 1 \\
\hline Beta-184244 & $\begin{array}{l}\text { House } 1 / 87 \text { post- } \\
\text { hole }\end{array}$ & $\begin{array}{l}\text { unidentified } \\
\text { wood charcoal }\end{array}$ & n.a. ${ }^{1}$ & $620 \pm 40$ & $\begin{array}{l}\text { cal AD } \\
1280-1410\end{array}$ & Cook 2007:Table 1 \\
\hline Beta-184245 & House $2 / 87$ hearth & $\begin{array}{l}\text { unidentified } \\
\text { wood charcoal }\end{array}$ & n.a. ${ }^{1}$ & $800 \pm 40$ & $\begin{array}{l}\text { cal AD } \\
1160-1280\end{array}$ & Cook 2007:Table 1 \\
\hline
\end{tabular}




\section{Corrected Proofs}

Table 1 SunWatch radiocarbon ages.

\begin{tabular}{|c|c|c|c|c|c|c|}
\hline Lab code & Context & Material & $\begin{array}{l}\delta^{13} \mathrm{C} \\
(\% 0)\end{array}$ & $\begin{array}{l}\text { Conv. }{ }^{14} \mathrm{C} \\
\text { age }(\mathrm{BP})\end{array}$ & $\begin{array}{l}\text { Calib. range } \\
(95 \% \text { conf.) }\end{array}$ & Reference \\
\hline$\overline{\text { Beta-20401 }}$ & $\begin{array}{l}\text { Feature } 1 / 79 \text { bell- } \\
\text { shaped pit }\end{array}$ & $\begin{array}{l}\text { unidentified } \\
\text { wood charcoal }\end{array}$ & n.a. ${ }^{1}$ & $660 \pm 60$ & $\begin{array}{l}\text { cal AD } \\
1260-1420\end{array}$ & $\begin{array}{l}\text { Nass 1987:296; Turn- } \\
\text { bow 1989:7 }\end{array}$ \\
\hline $\begin{array}{l}\text { SUERC- } \\
49909\end{array}$ & $\begin{array}{l}\text { Feature } 1 / 79 \text { bell- } \\
\text { shaped pit }\end{array}$ & $\begin{array}{l}\text { unidentified } \\
\text { nutshell }\end{array}$ & -27.5 & $692 \pm 32$ & $\begin{array}{l}\text { cal AD } \\
1260-1390\end{array}$ & This paper \\
\hline Beta-20402 & $\begin{array}{l}\text { Feature } 41 / 71 \\
\text { bell-shaped pit }\end{array}$ & $\begin{array}{l}\text { unidentified } \\
\text { wood charcoal }\end{array}$ & n.a. ${ }^{1}$ & $780 \pm 60$ & $\begin{array}{l}\text { cal AD } \\
1050-1390\end{array}$ & $\begin{array}{l}\text { Nass 1987:296; Turn- } \\
\text { bow 1989:7 }\end{array}$ \\
\hline Beta-20403 & $\begin{array}{l}\text { Feature 58/71 } \\
\text { bell-shaped pit }\end{array}$ & $\begin{array}{l}\text { unidentified } \\
\text { wood charcoal }\end{array}$ & n.a. ${ }^{1}$ & $560 \pm 80$ & $\begin{array}{l}\text { cal AD } \\
1270-1470\end{array}$ & $\begin{array}{l}\text { Nass 1987:296; Turn- } \\
\text { bow 1989:7 }\end{array}$ \\
\hline Beta-214767 & $\begin{array}{l}\text { Feature } 2 / 05 \text { bell- } \\
\text { shaped pit }\end{array}$ & $\begin{array}{l}\text { unidentified } \\
\text { wood charcoal }\end{array}$ & n.a. ${ }^{1}$ & $700 \pm 40$ & $\begin{array}{l}\text { cal AD } \\
1240-1400\end{array}$ & Cook 2007:Table 1 \\
\hline Beta-220063 & $\begin{array}{l}\text { Feature } 19 \mathrm{ww} / 74 \\
\text { bell-shaped pit }\end{array}$ & $\begin{array}{l}\text { unidentified } \\
\text { wood charcoal }\end{array}$ & -25.3 & $560 \pm 40$ & $\begin{array}{l}\text { cal AD } \\
1290-1440\end{array}$ & Cook 2007:Table 1 \\
\hline CWR-140 & $\begin{array}{l}\text { Feature } 10 / 73 \\
\text { central pole pit }\end{array}$ & $\begin{array}{l}\text { wood charcoal } \\
\text { (Juniperus } \\
\text { virginiana) }\end{array}$ & n.a. ${ }^{1}$ & $\begin{array}{l}820 \pm \\
110 / 120^{2}\end{array}$ & $\begin{array}{l}\text { cal AD } \\
980-1400\end{array}$ & $\begin{array}{l}\text { Shane 1975:364; Turn- } \\
\text { bow 1989:7; Wagner } \\
1979\end{array}$ \\
\hline CWR-141 & $\begin{array}{l}\text { Feature } 11 \mathrm{~s} / 72 \\
\text { bell-shaped pit }\end{array}$ & $\begin{array}{l}\text { unidentified } \\
\text { wood charcoal }\end{array}$ & n.a. ${ }^{1}$ & $\begin{array}{l}800 \pm \\
180 / 120^{2}\end{array}$ & $\begin{array}{l}\mathrm{cal} \text { AD } \\
770-1450\end{array}$ & $\begin{array}{l}\text { Shane 1975:364; Turn- } \\
\text { bow 1989:7 }\end{array}$ \\
\hline CWR-145 & $\begin{array}{l}\text { House } 2 / 72 \text {, Fea- } \\
\text { ture } 11 / 72 \text { (hearth) }\end{array}$ & $\begin{array}{l}\text { unidentified } \\
\text { wood charcoal }\end{array}$ & n.a. ${ }^{1}$ & $\begin{array}{l}820 \pm \\
150 / 160^{2}\end{array}$ & $\begin{array}{l}\text { cal AD } \\
880-1430\end{array}$ & $\begin{array}{l}\text { Shane 1975:364; Turn- } \\
\text { bow 1989:7-8 }\end{array}$ \\
\hline CWR-148 & $\begin{array}{l}\text { Feature 18/72 } \\
\text { bell-shaped pit }\end{array}$ & $\begin{array}{l}\text { unidentified } \\
\text { wood charcoal }\end{array}$ & n.a. ${ }^{1}$ & $900 \pm 160$ & $\begin{array}{l}\text { cal AD } \\
770-1400\end{array}$ & $\begin{array}{l}\text { Shane 1975:364; Turn- } \\
\text { bow 1989:7 }\end{array}$ \\
\hline $\begin{array}{l}\text { SUERC- } \\
49912\end{array}$ & $\begin{array}{l}\text { Feature } 18 / 72 \\
\text { bell-shaped pit }\end{array}$ & $\begin{array}{l}\text { unidentified } \\
\text { nutshell }\end{array}$ & -25.5 & $619 \pm 32$ & $\begin{array}{l}\text { cal AD } \\
1290-1410\end{array}$ & This paper \\
\hline CWR-151 & $\begin{array}{l}\text { Feature } 11 / 73 \\
\text { bell-shaped pit }\end{array}$ & $\begin{array}{l}\text { unidentified } \\
\text { wood charcoal }\end{array}$ & n.a. ${ }^{1}$ & $890 \pm 100$ & $\begin{array}{l}\text { cal AD } \\
960-1290\end{array}$ & $\begin{array}{l}\text { Shane 1975:364; Turn- } \\
\text { bow 1989:7 }\end{array}$ \\
\hline $\begin{array}{l}\text { SUERC- } \\
49911\end{array}$ & $\begin{array}{l}\text { Feature } 11 / 73 \\
\text { bell-shaped pit }\end{array}$ & $\begin{array}{l}\text { unidentified } \\
\text { nutshell }\end{array}$ & -26 & $617 \pm 32$ & $\begin{array}{l}\text { cal AD } \\
1290-1410\end{array}$ & This paper \\
\hline CWR-153 & $\begin{array}{l}\text { Feature } 3 / 73 \text { bell- } \\
\text { shaped pit }\end{array}$ & $\begin{array}{l}\text { unidentified } \\
\text { wood charcoal }\end{array}$ & n.a. ${ }^{1}$ & $\begin{array}{l}830 \pm \\
120 / 140^{2}\end{array}$ & $\begin{array}{l}\text { cal AD } \\
900-1410\end{array}$ & $\begin{array}{l}\text { Shane 1975:364; Turn- } \\
\text { bow 1989:7 }\end{array}$ \\
\hline DAL-141 & Storage pit & $\begin{array}{l}\text { unidentified } \\
\text { wood charcoal }\end{array}$ & n.a. ${ }^{1}$ & $295 \pm 100$ & $\begin{array}{l}\text { cal AD } \\
1430-1950\end{array}$ & $\begin{array}{l}\text { Ogden and Hart } \\
\text { 1977:398-9 }\end{array}$ \\
\hline I-7087 & $\begin{array}{l}\text { Feature 11/71 } \\
\text { bell-shaped pit }\end{array}$ & $\begin{array}{l}\text { charred maize } \\
\text { kernels }\end{array}$ & n.a. ${ }^{1}$ & $672 \pm 80^{3}$ & $\begin{array}{l}\text { cal AD } \\
1210-1430\end{array}$ & $\begin{array}{l}\text { Shane 1975:364; Turn- } \\
\text { bow 1989:2 }\end{array}$ \\
\hline $\begin{array}{l}\text { SUERC- } \\
49910\end{array}$ & $\begin{array}{l}\text { Feature } 11 / 71 \\
\text { bell-shaped pit }\end{array}$ & $\begin{array}{l}\text { charred maize } \\
\text { kernel }\end{array}$ & -7.8 & $673 \pm 32$ & $\begin{array}{l}\text { cal AD } \\
1270-1400\end{array}$ & This paper \\
\hline $\begin{array}{l}\text { SUERC- } \\
50376\end{array}$ & $\begin{array}{l}\text { Feature } 11 / 71 \\
\text { bell-shaped pit }\end{array}$ & $\begin{array}{l}\text { charred maize } \\
\text { kernel }\end{array}$ & -7.6 & $675 \pm 29$ & $\begin{array}{l}\text { cal AD } \\
1270-1390\end{array}$ & This paper \\
\hline M-1965 & $\begin{array}{l}\text { Feature } 6 / 8 \\
\text { straight-sided } \\
\text { storage pit }\end{array}$ & $\begin{array}{l}\text { unidentified } \\
\text { wood charcoal }\end{array}$ & n.a. ${ }^{1}$ & $640 \pm 100$ & $\begin{array}{l}\text { cal AD } \\
1180-1450\end{array}$ & $\begin{array}{l}\text { Crane and Griffin } \\
\text { 1970:166; Cook } \\
\text { 2008:67 }\end{array}$ \\
\hline OWU-448B & $\begin{array}{l}\text { Wall trench house, } \\
\text { wood on floor }\end{array}$ & $\begin{array}{l}\text { unidentified } \\
\text { wood charcoal }\end{array}$ & n.a. ${ }^{1}$ & $555 \pm 100$ & $\begin{array}{l}\text { cal AD } \\
1250-1630\end{array}$ & $\begin{array}{l}\text { Cook 2007:Table 1; Og- } \\
\text { den and Hay 1973:365; } \\
\text { Turnbow 1989:7-8 }\end{array}$ \\
\hline
\end{tabular}

${ }^{1}$ The $\delta^{13} \mathrm{C}$ values for the dates submitted before the 1990s have been lost and are currently not curated at any institution (William Kennedy, personal communication, 2013).

${ }^{2}$ Radiocarbon measurements with asymmetrical errors were not excluded from modeling and the larger of the two sides of their distributions was entered into $\mathrm{OxCal}$ as their $1 \sigma$ error

${ }^{3}$ The age for I-7087 (charred maize kernels, $395 \pm 80 \mathrm{BP}$ ) was originally corrected for fractionation using an assumed $-25 \%$. The age was recorrected using $-7.7 \%$, the average value derived from the two more recently dated maize kernels (Gordon Cook, personal communication, 2014). 


\section{Corrected Proofs}

Bayesian Chronological Modeling of SunWatch

\section{RADIOCARBON SAMPLING}

Single-entity samples of carbonized plant macrofossils dated by accelerator mass spectrometry (AMS) at Scottish Universities Environmental Research Centre (SUERC-) in 2013 were pretreated with acid-base-acid pretreatment (Stenhouse and Baxter 1983) then combusted in the manner described by Vandeputte et al. (1996) with the graphite targets prepared and measured following Naysmith et al. (2010). A multiple-entity sample of carbonized wood fragments (i.e. bulk charcoal) submitted for radiometric dating at the Michigan ${ }^{14} \mathrm{C}$ laboratory (M-) in the 1960 s was converted to gas and counted in the manner described by Crane (1961) with a $\mathrm{CO}_{2}-\mathrm{CS}_{2}$ Geiger counter system (Crane and Griffin 1970). Bulk samples of carbonized wood fragments submitted for radiometric dating to the Ohio Wesleyan University ${ }^{14} \mathrm{C}$ laboratory (OWU-) and the Dalhousie University ${ }^{14} \mathrm{C}$ laboratory (DAL-) in the 1970s were converted to methane and counted with a gas counter system (Ogden and Hart 1976, 1977; Ogden and Hay 1964, 1973).

There are further samples for which it is unclear exactly what pretreatment and measurement protocols were followed. Single-entity and bulk samples of wood charcoal fragments were submitted for radiometric dating to the Case Western Reserve ${ }^{14} \mathrm{C}$ laboratory in either the 1960 s or 1970 s. A bulk sample of carbonized plant macrofossils was submitted for radiometric dating to the Teledyne Isotopes ${ }^{14} \mathrm{C}$ laboratory in the same period. Single-entity samples of articulated human bone and carbonized wood fragments were submitted for AMS and radiometric dating to Beta Analytic in the 1980s-2000s. A single-entity sample of a plant macrofossil was submitted for AMS dating to the Illinois State Geological Survey in the 1990s.

The results of the available ${ }^{14} \mathrm{C}$ determinations are presented in Table 1, where they are quoted in accordance with the Trondheim convention (Stuiver and Kra 1986) as conventional ${ }^{14} \mathrm{C}$ ages (Stuiver and Polach 1977). Calibrated date ranges were calculated using the internationally agreed IntCal13 calibration curve of Reimer et al. (2013) and OxCal v 4.2 (Bronk Ramsey 1995, 1998, $2001,2009 \mathrm{a})$. They are cited in the text as $95 \%$ confidence intervals, with the end points rounded outwards to $10 \mathrm{yr}$.

\section{METHODOLOGY}

The technique used for Bayesian chronological modeling is a form of Markov chain Monte Carlo sampling (Buck et al. 1991, 1996), and has been applied using the program OxCal v 4.2 (http://c14. arch.ox.ac.uk/). Details of the algorithms employed by OxCal v 4.2 are available in Bronk Ramsey $(1995,1998,2001,2009 a)$ or from the online manual. The fit between the OxCal model and data is gauged with the $\mathrm{A}_{\text {model }}$ agreement index and values higher than 60 indicate good agreement between the model parameters and the dates (Bronk Ramsey 1995). Resulting posterior density estimates from $\mathrm{OxCal}$ are calendar years and presented in italics as probability ranges with end points rounded to the nearest $5 \mathrm{yr}$. The algorithms used in the models can be derived from the OxCal keywords and bracket structure shown in the probability distribution plots (Figures 3-6). It should be emphasized that the posterior density estimates produced by modeling are not absolute. They are interpretative estimates, which can and will change as further data become available and as other researchers choose to model the existing data from different perspectives.

\section{THE SAMPLES AND MODEL}

The village plan is organized around a large central post that was likely used to chart solar and stellar phenomena through alignment with village features (Heilman and Hoefer 1981; Goss 1988; Cook 2008). The stratigraphy of the central post pit indicates that the central post probably was replaced only once (Heilman and Hoefer 1981). Fragments of Eastern red cedar (Juniperus virginiana) that 


\section{Corrected Proofs}

had split away from the central post (Wagner 1979) were recovered from the central post pit. A single-entity fragment (CWR-140) of Eastern red cedar from this pit was submitted for dating.

Experimental archaeology and ethnographic comparison indicate that houses were probably used for 5 to $15 \mathrm{yr}$ (Cook 2005, 2008). Cook $(2005,2008)$ was able to further assess if individual houses were rebuilt based on an analysis of post-hole distribution and house area. Two ${ }^{14} \mathrm{C}$ results (Beta184243 and Beta-184244) are from single-entity samples of unidentified wood charcoal fragments found in the postholes of houses (House 2/71 and House 1/87) that have no evidence for rebuilding (Cook 2008). These wood charcoal fragments appear to be from the base of wall posts (Cook 2005), which were either burned in the act of tree felling (Hammerstedt 2005) or as a preventative measure against post decomposition (i.e. as one would use creosote in contemporary contexts).

$\mathrm{A}^{14} \mathrm{C}$ result (Beta-184242) is from a sample of unidentified wood charcoal found in a posthole associated with House $2 / 78$. This house constructed of mostly red cedar likely served as a ritual house or as the residence of a village leader (Robertson 1980, 1984; Cook 2004, 2008) and appears to have been rebuilt at least once based on an analysis of posthole distribution and house area (Cook 2005, 2008).

Two ${ }^{14} \mathrm{C}$ results (Beta-184245 and CWR-145) are from single-entity fragments of unidentified wood charcoal recovered from hearths within houses. Both houses (House 2/87 and House 2/72) appear not to have been rebuilt (Cook 2005, 2007). A ${ }^{14} \mathrm{C}$ result (OWU-448B) is from a single-entity piece of wood from a charred timber found on the floor of a wall trench house (Ogden and Hay 1973:365; Turnbow 1989:7-8; Cook 2007).

Burial 5/78 and Burial 8/74 each contained articulated adult males buried in an extended position (Cook and Schurr 2009). Single fragments of human bone were selected from each of these articulated human burials and the ${ }^{14} \mathrm{C}$ results (Beta-22062 and Beta-22061) date near the time of death. A straight-sided pit (Feature 6/8) is dated (M-1965) from a bulk sample of unidentified wood charcoal fragments found throughout the pit. Likewise, six bell-shaped pits (Features 41/71, 58/71, 2/05, $19 \mathrm{ww} / 74,11 \mathrm{~s} / 72$, and 3/73) are dated through ${ }^{14} \mathrm{C}$ results (Beta-20402, Beta-20403, Beta-214767, Beta-22063, CWR-141, and CWR-153) from single-entity samples of unidentified wood charcoal. A storage pit is dated through a ${ }^{14} \mathrm{C}$ result (DAL-141) from a single-entity sample of unidentified wood charcoal (Ogden and Hart 1977).

Three bell-shaped pit features (Features 11/73, 18/72, and 1/79) are dated through both ${ }^{14} \mathrm{C}$ results (CWR-151, CWR-148, and Beta-20401) from single-entity samples of unidentified wood charcoal and ${ }^{14} \mathrm{C}$ results (SUERC-49911, SUERC-49912, and SUERC-49909) from single-entity samples of unidentified nutshell. The results from unidentified nutshell are modeled as being from the use of pits because nutshell is a short-lived material, although there is a possibility that the nutshell may be residual.

A bell-shaped pit feature (1/77) is dated through a ${ }^{14} \mathrm{C}$ result (A-0175) from a bean. This result provides a time for the use of the feature because it is from a short-lived material. Another bellshaped pit feature (11/71) is dated through two ${ }^{14} \mathrm{C}$ results (SUERC-49910 and SUERC-50376) from single-entity samples of charred maize kernels and a ${ }^{14} \mathrm{C}$ result (I-7087) from a bulk sample of charred maize kernels. It is feasible that these samples are all the same age, as the measurements pass a chi-square test $\left[T=0.0 ; d f=2 ; T^{\prime}(0.05)=6.0\right]$; however, this might also suggest that the samples were deposited over an extremely short period of time. The youngest of these three ${ }^{14} \mathrm{C}$ dates (A-0175) provides the best estimate for the date of this context, and the remaining two dates (SUERC-49910 and SUERC-50376) are modeled as terminus post quos for this context. 


\section{Corrected Proofs}

Bayesian Chronological Modeling of SunWatch

The ${ }^{14} \mathrm{C}$ dates were placed in a single unordered phase with the prior assumption that they are representative of a single, relatively uniform phase of activity. Boundaries were placed around this phase in OxCal to estimate the start and end date of this unordered group. A charcoal outlier model (Bronk Ramsey 2009b) was adopted as a strategy for accounting for the unknown in-built age offset in wood charcoal samples in order to create a more accurate and robust model (Hamilton and Kenney 2015). The model assumes an exponential distribution, with an exponential constant $\tau$ of 1 taken over the range -10 to 0 , of the charcoal dates (Bronk Ramsey 2009b). The shifts are then scaled by a common scaling factor that can lie anywhere between $10^{0}$ and $10^{3} \mathrm{yr}$.

The algorithm used for the primary model can be directly derived from the model structure shown in Figure 3. The primary model shows good overall agreement $\left(\mathrm{A}_{\text {model }}=61.6\right)$ between the ${ }^{14} \mathrm{C}$ dates and the model assumptions. The model estimates that the earliest activity on the site began in $c a l A D$ 1175-1385 (95\% probability; Figure 3a; Start: SunWatch), and probably in cal AD 1225-1380 (68\% probability). Occupations are estimated to have continued for the next $1-245 \mathrm{yr}(95 \% \mathrm{prob}-$ ability; Figure 4), and probably for $1-180 y r$ (68\% probability). Activity on the site is estimated to have ended in cal AD 1330-1470 (95\% probability; Figure 3a; End: SunWatch), and probably in cal AD 1365-1415 (68\% probability).

\section{SENSITIVITY ANALYSIS}

An alternative Bayesian model was created using $18{ }^{14} \mathrm{C}$ dates from contexts based on horizontal stratigraphy. This approach is justified on the basis of stockade positioning as well as temporally sensitive artifact concentrations in pit groups where dated materials were located (Cook 2008:Figure 4.11, Table 4.2). If a sample was in a pit group lacking multiple indicators of being relatively recent [i.e. Occupation Group A (Cook 2008: Table 4.2)] or from a structure deemed to be early in the sequence based on stockade superpositioning or rebuilding evidence, it was placed in Group 1 in the present study. Conversely, if a sample was in a pit group with multiple indicators of being relatively recent [i.e. Occupation Group B or C (Cook 2008:Table 4.2)] or from a structure outside of earlier stockade lines, it was placed in Group 2 in the present study.

Ten ${ }^{14} \mathrm{C}$ results (A-0175, Beta-184243, Beta-20402, Beta-20403, CWR-140, CWR-148, SUERC-49912, CWR-151, SUERC-49911, and CWR-153) are from contexts associated with Group 1, and eight ${ }^{14} \mathrm{C}$ results (Beta-220062, Beta-220061, Beta-184242, Beta-184244, Beta220063, DAL-141, M-1965, and OWU-448B) are from contexts associated with Group 2. The ${ }^{14} \mathrm{C}$ dates were placed in unordered phases corresponding with these two groups, with the prior assumption that they are representative of two single, relatively uniform phases of activity. Boundaries were placed around the phases in OxCal to estimate the start and end date of the two unordered groups.

A charcoal outlier model (Bronk Ramsey 2009b), with the same assumptions as the primary model, was adopted as a strategy for accounting for the unknown in-built age offset in wood charcoal samples. The algorithm used for the alternative model can be directly derived from the model structure shown in Figure 5. The alternative model shows good overall agreement $\left(\mathrm{A}_{\text {model }}=88\right)$ between the ${ }^{14} \mathrm{C}$ dates and the model assumptions. The model estimates that activity associated with Group 1 on the site began in cal AD 1030-1325 (95\% probability; Figure 6; Start: SunWatch: Group 1), and probably in cal AD 1155-1310 (68\% probability). Activity associated with Group 1 on the site is estimated to have ended in cal AD 1295-1465 (95\% probability; Figure 6; End: SunWatch: Group 1), and probably in cal $A D 1305-1405$ (68\% probability). The model estimates that activity associated with Group 2 on the site began in cal AD 1210-1385 (95\% probability; Figure 6; Start: SunWatch: Group 2), and probably in cal AD 1265-1375 (68\% probability). Activity associated with Group 2 on the site is estimated to have ended in cal AD 1335-1635 (95\% probability; Figure 6; End: SunWatch: Group 2), and probably in cal AD 1365-1510 (68\% probability). 


\section{Corrected Proofs}

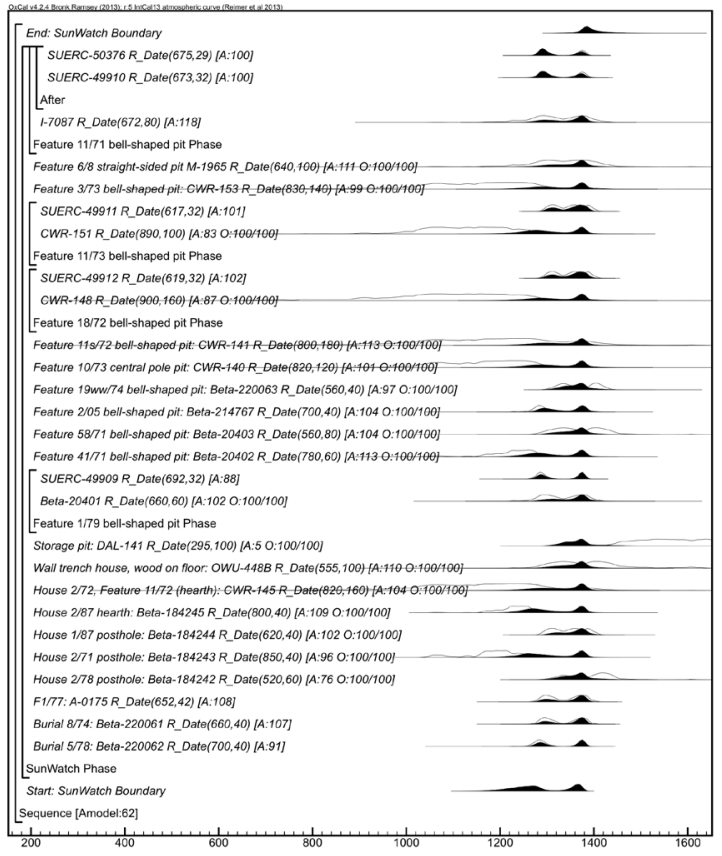

(a)

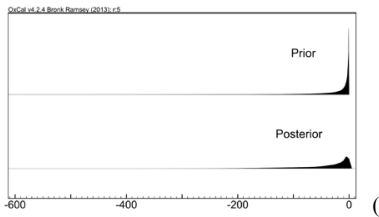

Figure 3 (a) Results and structure of the primary model. The brackets and keywords define the model structure. The outlined distribution is the result of ${ }^{14} \mathrm{C}$ calibration and the solid distributions are the chronological model results. The large square "brackets" along with the OxCal keywords define the overall model exactly. In the lower left plot (b), both the effective prior (from Equation 88 in Bronk Ramsey 2009b) and the posterior distribution of the outlier offsets $\left(10^{u} \delta_{i}\right)$ are shown. The posterior distribution of the outlier offsets provides an estimate for the charcoal ages. In the lower right plot (c), the estimated timescale (in powers of 10) for charcoal residuality (the posterior distribution for $u$ with the uniform prior shown in outline) is shown.

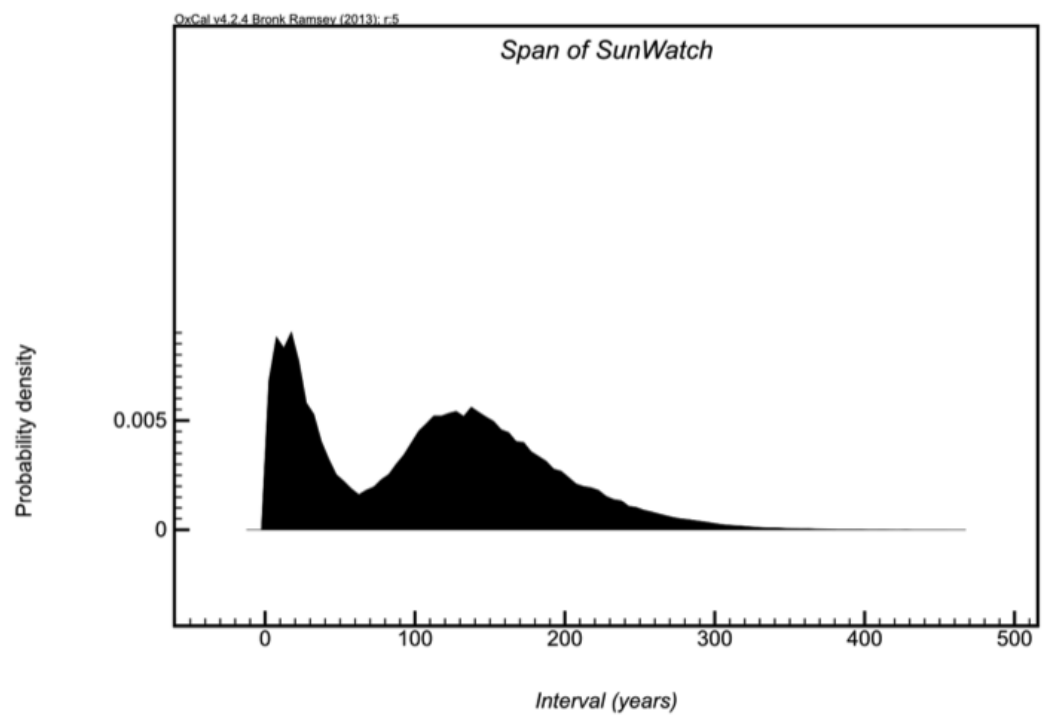

Figure 4 Probability distributions for the span of occupation at SunWatch in the primary model. The probabilities are derived from the modeling shown in Figure 3. 


\section{Corrected Proofs}

Bayesian Chronological Modeling of SunWatch

Figure 5 Results and structure of the alternative model (a). The brackets and keywords define the model structure. The format is as described in Figure 3. In the lower left plot (b) both the effective prior (from Equation 88 in Bronk Ramsey 2009b) and the posterior distribution of the outlier offsets $\left(10^{u} \delta_{i}\right)$ are shown. The posterior distribution of the outlier offsets provides an estimate for the charcoal ages. In the lower right plot (c), the estimated timescale (in powers of 10) for charcoal residuality (the posterior distribution for $u$ with the uniform prior shown in outline) is shown.

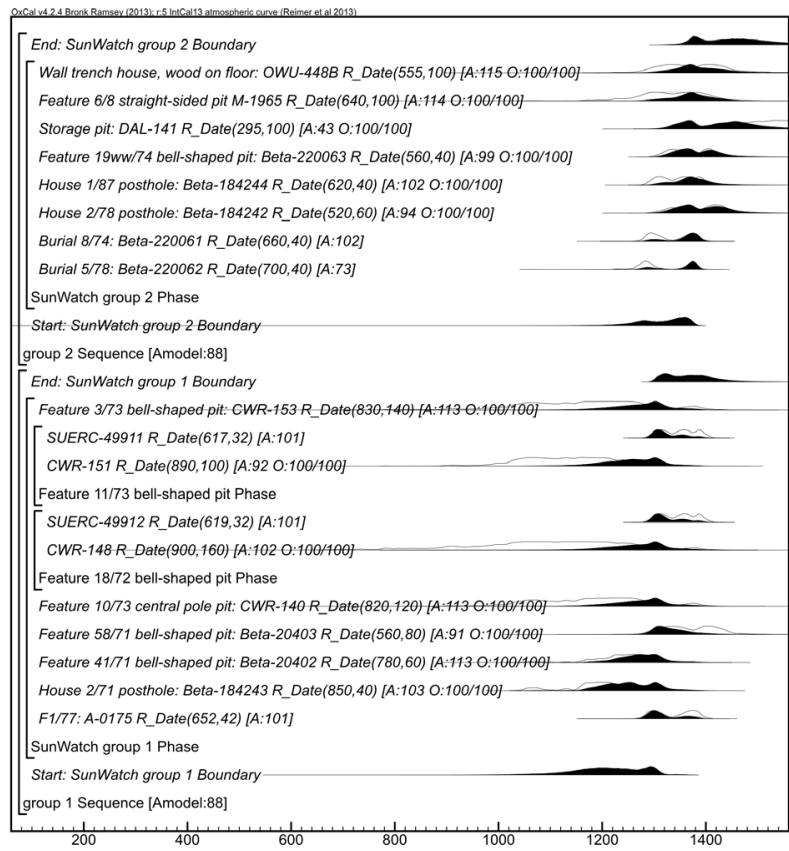

(a) Modelled date ( $A D)$

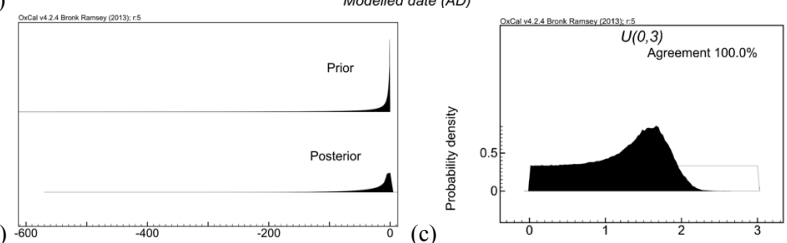

(b) -6

(c)

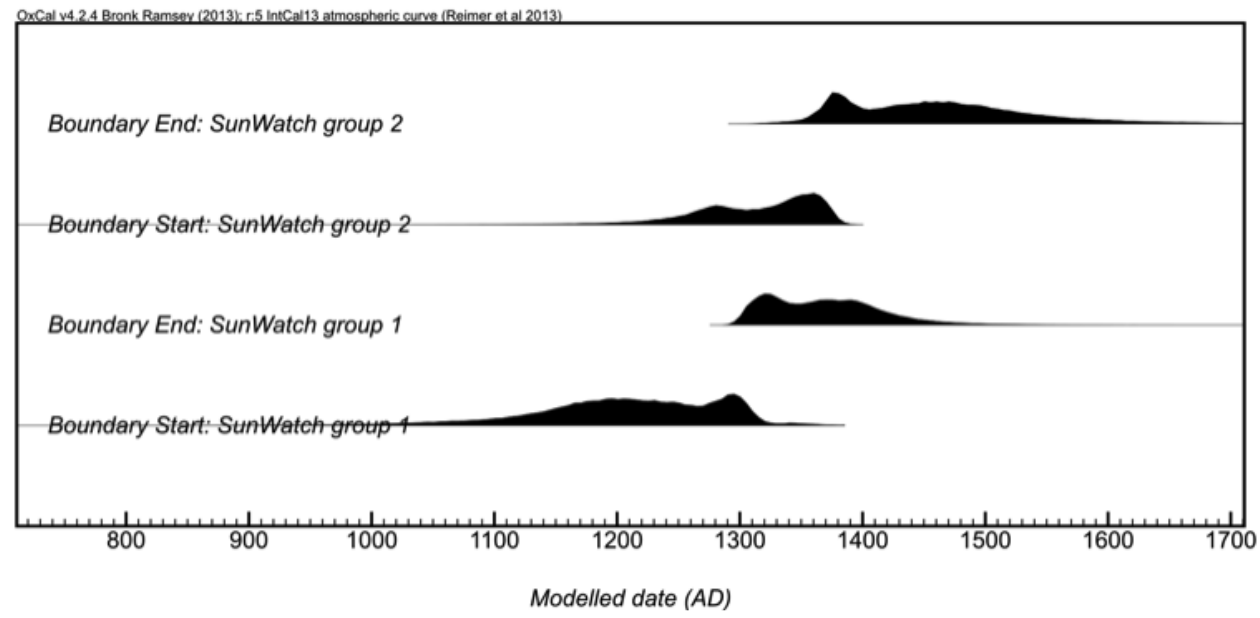

Figure 6 Posterior probabilities from Figure 5a for the starting and ending boundaries for unordered phases corresponding with Group 1 and Group 2 in the alternative model. 


\section{Corrected Proofs}

\section{DISCUSSION}

SunWatch is an interesting case in comparison to Fort Ancient villages in the study region that are either more clearly multiple or singular component sites. Multiple component villages have several relatively distinct and often overlapping rings of features with a correspondingly long range of ${ }^{14} \mathrm{C}$ dates (e.g. Madisonville [Drooker 1997]), whereas singular component villages have rings of non-overlapping features with no indications of expansion or contraction of settlement patterning along with a much narrower range of ${ }^{14} \mathrm{C}$ dates [e.g. Horseshoe Johnson (Cook and Comstock 2014a,b)]. In contrast to these ends of the spectrum, SunWatch has some feature overlap and clear indications of growth over time in the village but lacks indications of staggered village patterns. The question is, how much time is represented and whether it is feasible that the site was abandoned for some period of time?

A single occupation of a few human generations is supported by the results of the primary model (Figures 3-4) and adheres best with archaeological patterning at the site (i.e. villages that are reused after long periods of abandonment have staggered plans and overlapping features). If a single occupation occurred, it likely began in the $\mathrm{AD} 1300$ s and ended in cal AD 1365-1415 (68\% probability; Figure 3a; End: SunWatch), although a starting date in the AD 1200s cannot be discounted.

Alternatively, if there were two occupations with a lengthy gap between them, then the gap between occupations was probably not for more than the standing use-life of the Eastern red cedar center pole because this pole may have been extremely long lived (Stockton Maxwell et al. 2011) and served as the only way occupants could relocate the settlement and identify previous settlement layouts (Cook 2004, 2007). In this scenario, reoccupation would have likely occurred after only a short hiatus as key features were relocated and rebuilt (Cook 2007). If this occurred, then the first occupation likely began in cal AD 1155-1310 (68\% probability; Figure 6; Start: SunWatch: Group 1) and ended in cal AD 1305-1405 (68\% probability; Figure 6; End: SunWatch: Group 1), and the second occupation likely began in cal AD 1265-1375 (68\% probability; Figure 6; Start: SunWatch: Group 2) and ended in cal AD 1365-1510 (68\% probability; Figure 6; End: SunWatch: Group 2).

A few additional lines of evidence are relevant in further considering the nature of SunWatch's occupation. First, there are ethnographic cases of villages being used intermittently for relatively long periods of time; for example, the Big Village of the Omaha was used at different times for 70 yr (O'Shea and Ludwickson 1992:1). Dorsey (1886:222) states, "the Omahas have remained in a permanent village for 10 years at a time, and have returned repeatedly to such an old village." Second, an independent study of occupation duration for SunWatch based on pottery breakage rates in comparison to ethnographic cases indicated the site could have been used for a range of 68-101 yr (Sunderhaus and Cook 2011). Considering this information leads us to tentatively lean toward the conclusion that there were at least two different uses of the site considering the likelihood that local resource depletion would have become a factor after a few generations and the low end of the pottery breakage estimate exceeds this threshold.

The wide ranges of the posterior density estimates for the start and end of Group 1 and Group 2 in the alternative model (Figure 6) are due in some part to the abundance of dates with large errors (Table 1). While the start of Group 1 predates Group 2 (Figure 6), the alternative modeling does not indicate that there is any discernable gap in time between the two groups, although the alternative modeling does suggest that there might be short phases of about a generation around Group 1 and Group 2 (Figure 6). Steier and Rom (2000), Bayliss et al. (2007), and Griffiths (2014) demonstrate that simulation models can be useful tools for estimating the number of additional ${ }^{14} \mathrm{C}$ dates needed to reach a desired level of temporal resolution. Simulated dates were added to the alternative model to identify if further dat- 


\section{Corrected Proofs}

Bayesian Chronological Modeling of SunWatch

ing might be able to resolve whether the two groups can truly be two separate phases with a gap of time between. These simulations indicated that if this is a reality, then a minimum of five additional well-chosen short-lived specimens dated from each group could resolve the issue.

\section{CONCLUSION}

The analysis presented herein provides an example of what type of Bayesian modeling can be done with legacy dates that were not selected with a Bayesian approach in mind and an example of how to critically evaluate such legacy dates for a Bayesian analysis. The Bayesian analysis for SunWatch has estimated a chronology that is now at a higher resolution than before. A single occupation of a few human generations is supported by the Bayesian modeling (Figure 3-4) and adheres best with archaeological patterning at the site (Figure 2). A multicomponent occupation is also feasible given the results of the primary model (Figure 3-4) and that there is some temporal separation between two distinct groups (Figure 6). If two occupations occurred, then the second would most likely have been after only a short hiatus as key features were relocated and rebuilt (Cook 2007). A consideration of the comparative ethnohistoric evidence (O'Shea and Ludwickson 1992:1; Sunderhaus and Cook 2011) leads us to lean towards the conclusion that there were at least two different uses of the site. While it is difficult to determine if SunWatch had a single-component or multicomponent occupation, it is clear that SunWatch's occupation lasted until the second half of the AD 1300s.

A goal for future research on SunWatch is to create a more robust AMS ${ }^{14} \mathrm{C}$ data set through the submission of single entities of articulated bone or short-lived material that can be determined from excavation records to be strongly related to the function of the context from which they were recovered, such as wood charcoal from a hearth. Ideally, a robust chronology will be created through substantial dating from materials found in a variety of features to put together a more refined settlement chronology and provide further insight into the history of the Eastern Woodlands.

\section{ACKNOWLEDGMENTS}

Christopher Bronk Ramsey provided valuable assistance via email to improve our understanding of charcoal outlier modeling. William Kennedy and the Boonshoft Museum of Discovery staff kindly assisted with this work by accessing and discussing information about curated documents and artifacts. Gordon Cook and the staff of the Radiocarbon Dating Laboratory at the Scottish Universities Environmental Research Centre kindly oversaw the ${ }^{14} \mathrm{C}$ dating of five samples. Three anonymous reviewers provided helpful and thoughtful comments.

\section{REFERENCES}

Aitken MJ. 1990. Science-Based Dating in Archaeology. London: Longman.

Baillie MGL. 1991. Suck-in and smear: two related chronological problems for the 90s. Journal of Theoretical Archaeology 2:12-6.

Bayliss A. 2009. Rolling out revolution: using radiocarbon dating in archaeology. Radiocarbon 51(1):12347.

Bayliss A, Bronk Ramsey C, van der Plicht J, Whittle A. 2007. Bradshaw and Bayes: towards a timetable for the Neolithic. Cambridge Archaeological Journal 17(S1):1-28.

Bayliss A, van der Plicht J, Bronk Ramsey C, McCormac G, Healy F, Whittle A. 2011. Towards generational time-scales: the quantitative interpretation of archaeological chronologies. In: Whittle A, Healy F, Bayliss A, editors. Gathering Time: Dating the Ear- ly Neolithic Enclosures of Southern Britain and Ireland. Oxford: Oxbow Books. p 17-59.

Bronk Ramsey C. 1995. Radiocarbon calibration and analysis of stratigraphy: the OxCal program. Radiocarbon 37(2):425-30.

Bronk Ramsey C. 1998. Probability and dating. Radiocarbon 40(1):461-74.

Bronk Ramsey C. 2001. Development of the radiocarbon calibration program. Radiocarbon 43(2A):355-63.

Bronk Ramsey C. 2009a. Bayesian analysis of radiocarbon dates. Radiocarbon 51(1):337-60.

Bronk Ramsey C. 2009b. Dealing with outliers and offsets in radiocarbon dating. Radiocarbon 51(3):1023-45.

Brose DS. 1982. The archaeological investigation of a Fort Ancient community near Ohio Brush Creek, Adams County, Ohio. Kirtlandia 34:1-69 


\section{Corrected Proofs}

Buck CE, Kenworthy JB, Litton CD, Smith AFM. 1991 Combining archaeological and radiocarbon information: a Bayesian approach to calibration. Antiquity 65(249):808-21.

Buck CE, Cavanagh WG, Litton CD. 1996. Bayesian Approach to Interpreting Archaeological Data. Chichester: John Wiley \& Sons.

Cook RA. 2004. Upper Mississippian village structure and formation: spatial analysis of SunWatch, a Fort Ancient site in southwest Ohio [PhD dissertation]. East Lansing: Michigan State University.

Cook RA. 2005. Reconstructing perishable architecture: prospects and limitations of a Fort Ancient example. North American Archaeologist 26:357-88.

Cook RA. 2007. Single component sites with long sequences of radiocarbon dates: the SunWatch Site and Middle Fort Ancient village growth. American Antiquity 72(3):439-60.

Cook RA. 2008. SunWatch: Fort Ancient Development in the Mississippian World. Tuscaloosa: University of Alabama Press.

Cook RA, Comstock AR. 2014a. Evaluating the old wood problem in a temperate climate: a Fort Ancient case study. American Antiquity 79(4):763-75.

Cook RA, Comstock AR. 2014b. Toward more continuous and practical artifact analyses: defining and learning from key dimensions of Fort Ancient triangular projectile points in the Miami Valleys. Midcontinental Journal of Archaeology 39:222-50.

Cook RA, Schurr MR. 2009. Eating between the lines: Mississippian migration and stable carbon isotope variation in Fort Ancient populations. American Anthropologist 111(3):344-59.

Cowan CW, Dunavan S, Nass, JP, Scott S. 1990. The Schomaker site: a Middle Period Fort Ancient town on the Great Miami River, Hamilton County, Ohio. West Virginia Archaeologist 42:11-35.

Crane HR. 1961. $\mathrm{CO}_{2}-\mathrm{CS}_{2}$ Geiger counter. The Review of Scientific Instruments 32(8):953-62.

Crane HR, Griffin JB. 1970. University of Michigan radiocarbon dates XIII. Radiocarbon 12(1):161-80.

Dorsey JO. 1886. Migrations of Siouan tribes. The American Naturalist 20:211-22.

Drooker PB. 1997. The View from Madisonville: Protohistoric Western Fort Ancient Interaction Patterns. Ann Arbor: Museum of Anthropology, Memoirs No. 31, University of Michigan.

Goss AF. 1988. Astronomical alignments at the Incinerator Site. In: Heilman JM, Lileas MC, Turnbow CA, editors. History of 17 Years of Excavation and Reconstruction: A Chronicle of 12th Century Human Values and the Built Environment. Dayton: Dayton Museum of Natural History. p 314-35.

Griffiths S. 2014. Simulations and outputs. Radiocarbon 56(2):871-6.

Hamilton WD, Kenney J. 2015. Multiple Bayesian modelling approaches to a suite of radiocarbon dates from ovens excavated at Ysgol yr Hendre, Caernarfon, North Wales. Quaternary Geochronology 25:75-82.
Hammerstedt SW. 2005. Mississippian construction, labor, and social organization in western Kentucky [PhD dissertation]. State College: Pennsylvania State University.

Hanson LH. 1975. The Buffalo Site. Morgantown: West Virginia Geological and Economic Survey.

Hart JP, Asch DL, Scarry CM, Crawford GW. 2002. The age of the common bean (Phaseolus vulgaris L.) in the northern Eastern Woodlands of North America. Antiquity 76(292):377-85.

Heilman JM, Hoefer R. 1981. Possible astronomical alignments in a Fort Ancient settlement at the Incinerator Site in Dayton, Ohio. In: Williamson R, editor. Archaeoastronomy in the Americas. Menlo Park: Ballena Press. p 157-71.

Heilman JM, Lileas MC, Turnbow CA, editors. 1988. A History of 17 Years of Excavation and Reconstruction: A Chronicle of 12th Century Human Values and the Built Environment. Dayton: Dayton Museum of Natural History.

Henderson AG. 1998. Middle Fort Ancient villages and organizational complexity in Kentucky [PhD dissertation]. Lexington: University of Kentucky.

Henderson AG, Pollack D, Turnbow CA. 1992. Chronology and cultural patterns. In: Henderson AG, editor. Fort Ancient Cultural Dynamics in the Middle Ohio Valley. Madison: Prehistory Press. p 253-79.

Jay M, Haselgrove C, Hamilton D, Hill JD, Dent JS. 2012. Chariots and context: new radiocarbon dates from Wetwang and the chronology of Iron Age burials and brooches in East Yorkshire. Oxford Journal of Archaeology 31(2):161-89.

Nass JP. 1987. Use-wear analysis and household archaeology: a study of the activity structure of the Incinerator Site, and Anderson Phase Fort Ancient community in southwestern Ohio [PhD dissertation]. Columbus: Ohio State University.

Naysmith P, Cook G, Freeman S, Scott EM, Anderson R, Dunbar E, Muir G, Dougans A, Wilcken K, Schnabel C, Russell N, Ascough P, Maden C. $2010 .{ }^{14} \mathrm{C}$ AMS at SUERC: improving QA data from the 5MV tandem AMS and 250kV SSAMS. Radiocarbon 52(2):263-71.

Nolan KC. 2011. Distributional survey of the Reinhardt Site (33PI880), Pickaway County, Ohio: a strategy for deciphering the community structure of a Fort Ancient village. Midcontinental Journal of Archaeology 36:105-30.

Nolan KC. 2012. Temporal hygiene: problems in cultural chronology of the Late Prehistoric Period of the Middle Ohio River Valley. Southeastern Archaeology 31:185-206.

Ogden JG, Hart WC. 1976. Dalhousie University natural radiocarbon measurements I. Radiocarbon 18(1):43-9.

Ogden JG, Hart WC. 1977. Dalhousie University natural radiocarbon measurements II. Radiocarbon 19(3):392-9.

Ogden JG, Hay RJ. 1964. Ohio Wesleyan University 


\section{Corrected Proofs}

Bayesian Chronological Modeling of SunWatch

natural radiocarbon measurements I. Radiocarbon 6:340-8.

Ogden JG, Hay RJ. 1973. Ohio Wesleyan University natural radiocarbon measurements V. Radiocarbon 15(2):350-66.

O'Shea JM, Ludwickson J. 1992. Archaeology and Ethnohistory of the Omaha Indians: The Big Village Site. Lincoln: University of Nebraska Press.

Prufer OH, Shane OC. 1970. Blain Village and the Fort Ancient Tradition in Ohio. Kent: Kent State University Press.

Reimer PJ, Bard E, Bayliss A, Beck JW, Blackwell PG, Bronk Ramsey C, Grootes PM, Guilderson TP, Haflidason H, Hajdas I, Hatté C, Heaton TJ, Hoffmann DL, Hogg AG, Hughen KA, Kaiser KF, Kromer B, Manning SW, Niu M, Reimer RW, Richards DA, Scott EM, Southon JR, Staff RA, Turney CSM, van der Plicht J. 2013. IntCal13 and Marine13 radiocarbon age calibration curves $0-50,000$ years cal BP. Radiocarbon 55(4):1869-87.

Robertson JA. 1980. Chipped stone and socio cultural interactions [Master's thesis]. Chicago: University of Illinois at Chicago.

Robertson JA. 1984. Chipped stone and functional interpretations: a Fort Ancient example. Midcontinental Journal of Archaeology 9:251-67.

Shane OC. 1975. Appendix: Ohio radiocarbon chronology. In: Prufer OH, McKenzie DH, editors. Studies in Ohio Archaeology. Revised edition. Kent: Kent State University Press. p 357-68.

Steier P, Rom W. 2000. The use of Bayesian statistics for ${ }^{14} \mathrm{C}$ dates of chronologically ordered samples: a critical analysis. Radiocarbon 45(2):183-98.

Stenhouse MJ, Baxter MS. 1983. ${ }^{14} \mathrm{C}$ reproducibility: evidence from routine dating of archaeological samples. PACT 8:147-1.

Stockton Maxwell R, Hessl AE, Cook ER, Buckley BM. 2011. A multicentury reconstruction of May precipitation for the Mid-Atlantic region using $\mathrm{Ju}$ niperus virginiana tree rings. Journal of Climate 25(3):1045-56.

Stuiver M, Kra RS. 1986. Editorial comment. Radiocarbon 28(2B):ii.

Stuiver M, Polach HA. 1977. Discussion: reporting of ${ }^{14} \mathrm{C}$ data. Radiocarbon 19(3):355-63.

Sunderhaus TS, Cook RA. 2011. Making and breaking pots in a Late Prehistoric village in the Midwest United States. North American Archaeologist 32:49-80.

Turnbow C. 1989. Radiocarbon Determinations of the SunWatch Site (33My57). Department of Anthropology, Boonshoft Museum of Discovery, Dayton, Ohio.

Vandeputte K, Moens L, Dams R. 1996. Improved sealed-tube combustion of organic samples to $\mathrm{CO}_{2}$ for stable isotope analysis, radiocarbon dating and percent carbon determinations. Analytical Letters 29(15):215-30.

Wagner GE. 1979. Wood in a 1200 A.D. Stockaded Village. Annual meeting of the Society for Economic Botany. Raleigh, North Carolina. 